\title{
COMMENT
}

\section{THE UNTTED STATES AND PLANS FOR A UNIFORM (WORLD) LAW ON INTERNATIONAL SALES OF GOODS}

\author{
KURT H. NaDELMaNN $\dagger$
}

A diplomatic conference will open at The Hague on April 2, 1964 to consider the draft of a Uniform Law on International Sales of Goods. This country has not participated in the preparation of the draft, yet any agreement reached by other nations on a uniform law will affect American interests.

The history of the project can be traced to the days of the League of Nations, when Mussolini offered the League his government's backing for an institution, situated in Rome, which would work on unification of law. The Rome Institute, formally called the International Institute for the Unification of Private $\mathrm{Law},{ }^{1}$ in 1930 appointed a committee, composed of experts from England, France, Germany, and Sweden, ${ }^{2}$ to draft a uniform law on international sales of goods. A first draft was communicated by the League of Nations to the governments for their comments in $1935 .^{3}$ On the basis of these comments, the committee prepared a revised draft consisting of 105 articles, which became available in 1939.4 After the war, the Rome Institute, transformed into a permanent international institution, ${ }^{5}$ suggested to the government of the Netherlands that it call a

†Research Scholar, Harvard Law School. Adjunct Associate Professor of Law, New York University. J.U.D. 1921, Freiburg i. Br.; Lic. en droit 1934, Paris.

1 For a history of the Institute see INTERNATIONAI INSTITUTE FOR THE UNIFICATION OF PRIVATE LAW, 1948 UNIFICATION OF LAW 15 [hereinafter cited as UNIFICATION OF LAW].

2 The committee was composed of Sir Cecil Hurst (United Kingdom), chairman; Judge Algot Bagge (Sweden) ; Professor Henri Capitant (France); Professor Martin Fehr (Sweden); Professor H. C. Gutteridge (United Kingdom); Professor Joseph Hamel (France); and Professor Ernst Rabel (Germany).

3 INSTITUT INTERNATIONAL DE ROME POUR I'UNIFICATION DU DROIT PRIVE, SOCIÉTÉ des Nations, Projet d'UNe loi SUR LA vente internationale des objets mobiliers CORPORELS (1935).

4 INSTITUT INTERNATIONAI DE ROME POUR I'UNIFICATION DU DROIT PRIVÉ, SOCIÉtÉ des Nations, Projet d'une loi sur la vente internationale des objets MobiliERS CORPORELS ET RAPPORT (1939). The text is reprinted in 1948 UNIFICATION OF LAw 102-59.

5ee 1948 Unification of Law 17. The Rome Institute is at present supported by more than forty nations, including all Western nations of the Continent, the United Kingdom, Ireland, eleven Latin-American states, Turkey, Iran, Israel, Egypt, Japan, Hungary, Bulgaria, Romania, and Yugoslavia. 
diplomatic conference to consider the revised draft. The Conference took place at The Hague from November 1 to $10,1951$.

At the Conference on the Uniform Sales Law twenty-one nations, ${ }^{6}$ the United Nations, the Rome Institute, and the International Chamber of Commerce were represented. Observers were present for five countries including the United States. ${ }^{7}$ The silent observer for the United States Government was a Second Secretary of the Embassy at The Hague. ${ }^{8}$ The Rome Institute was represented by Dr. Ernst Rabel ${ }^{9}$ who took an active part in the proceedings. As director of the Institute of Comparative and Private International Law in Berlin, he had brought out in 1936 a comparative study of the law of sales in the world, which is the basic working tool on the subject matter. ${ }^{10}$

The Diplomatic Conference of 1951 accepted the Rome Institute draft as a basis for future work. After ten days of discussions it appointed a Special Committee to revise the draft. ${ }^{11}$ The Special Committee's revised draft, consisting of 113 articles and a supporting statement, became available in $1956 .{ }^{12}$ Thirteen governments, ${ }^{13}$ as well as the International Chamber of Commerce, then submitted comments which were used by the Special Committee in further refining its draft. ${ }^{14}$ The revised "final" draft," accompanied by

6 Austria, Belgium, Denmark, Finland, France, West Germany, Greece, Ireland, Italy, Japan, Luxembourg, the Netherlands, Norway, Portugal, San Marino, Spain, Sweden, Switzerland, the United Kingdom, and the Vatican City. Conférence sur UN PROJET DE CONVENTION RELATIF A UNE LOI UNIFORME SUR LA VENTE D'OBJETS MOBILIERS CORPORELS, ACTES DE LA CONFÉRENCE 21 (1952) [hereinafter cited as AcTes].

7 The others were Bolivia, Chile, Cuba, and Yugoslavia.

$8 \mathrm{Mr}$. Charles Ph. Clock.

9 Author of 1-4 The Conflict of Laws: A Comparative Study (1945, 1947, 1950, 1958).

101 Rabel, Das Recht des Warenkaufs (1936). A second volume was published posthumously in 1958. For a discussion of the book see Cohn, $A$ Unified Law of Sale of Goods, 21 J. CoMp. LEG. \& INT'L L. (3d ser.) 244 (1939).

11 See ACTES 269. The members of the Special Committee are: M. Pilotti (Italy), chairman; V. Angeloni (Italy); A. Bagge (Sweden); F. de Castro y Bravo (Spain); L. Fredericq (Belgium); M. Gutzwiller (Switzerland); J. Hamel, assisted by A. Tunc (France); E. M. Meijers, replaced by F. van der Feltz (Netherlands); E. Rabel, replaced by T. Ascarelli (Rome Institute); O. Riese (West Germany); H. Ussing (Denmark); B. A. Wortley (United Kingdom).

12 Commission Spectale nommée par la Conférence de La Haye sur la VENTE, PROJET D'UNE LOT UNIFORME SUR LA VENTE INTERNATIONALE DES OBJETS Mobiliers corporels, Nouveau TEXTe Élaboré par la CoMmission et RapPort de LA Commission (1956) [author hereinafter cited as Commissron Speciale].

13 Austria, Denmark, France, West Germany, Hungary, Italy, Luxembourg, the Netherlands, Norway, Portugal, Sweden, Switzerland, and the United Kingdom.

14 See Commisston Spéciale, Observations Des Gouvernements et DE LA CCI SUR LE PROJET DE LOI UNIFORME SUR LA VENTE INTERNATIONALE DES OBJETS MOBILIERS CORPORELS (1963).

15 Commisston Spéctale, Projet d'une lor uniforme sur la vente internaTIONALE DES OBJETS MOBILIERS CORPORELS, TEXTE DES ARTICLES MIODIFIÉS SELON LES proposttions de la CoMmission Spéciale eñ 1962/1963 (1963). 
comments, ${ }^{16}$ available since April 1963, will be the basis for discussions of the Diplomatic Conference called to meet for three weeks beginning April 2, 1964. ${ }^{17}$

We have noted the lack of American participation in the drafting. However, the original committee was fully familiar with the AngloAmerican law of sales at the time, and many features of that law were adopted for the draft. On the other hand, the chief reporter for the revision of the Uniform Sales Act of 1906, Professor Karl N. Llewellyn, was well acquainted with the work of the Rome Institute and Continental sales law. ${ }^{18}$ Important features of the new American sales law, as expressed by the sales article in the Uniform Commercial Code, especially the deemphasis of the concept of title and a shift from property to contract, ${ }^{19}$ are in accord with what is found in the draft for the coming Conference. At least until Dr. Rabel's death in 1955, the Special Committee appointed by the Diplomatic Conference was kept briefed on the progress of the work on the Uniform Commercial Code. ${ }^{20}$

Under the standards developed by the National Conference of Commissioners on Uniform State Laws, unification of a branch of the law must be both desirable and practicable to be undertaken by

16 Commission Spéclale, Note de la Comimission Spéciale sur les ObservaTIONS PRÉSENTÉES PAR DIVERS GOUVERNEMENTS SUR LE PROJET DE LOT UNIFORAIE SUR LA VENTE INTERNATIONALE DES OBJETS MOBLIERS CORPORELS (1963).

17 While little noticed by the legal profession in this country, literature in English on these doings is not lacking. The Revised Draft of 1939 appears in an English translation in 1948 UNIFICATION OF LAW 103-59. An English translation of the Committee Draft of 1956 appears in 7 INT'L \& CoMr. L.Q. 3 (1958) with an introduction by Professor B. A. Wortley. Other publications on the subject are: Gutteridge, An International Code of the Law of Sales, 14 BR. YB. INT'L L. 75 (1933); Rabel, A Draft of an International Law of Sales, 5 U. CHI. L. REv. 543 (1938); Rabel, $A$ Draft of a Uniform Lawe Concerning International Sales of Goods, in 1948 UnIFICATION of Law 57; Rabel, The Sales Law in the Proposed Commercial Code, 17 U. ChI. L. Rev. 427 (1950); Rabel, International Sales Law, in 1949 Summer Institute on International and Comparative Law, Lectures on the Conflict of Laws and International Contracts 34 (1951); Rabel, The Hague Conference o13 the Unification of Sales Law, 1 AM. J. CoMp. LAw 58 (1952); Keyes, Toward a Single Law Governing the International Sales of Goods-A Comparative Study, 42 CalrF. L. REv. 653 (1954); Honnold, A Uniforn Law for International Sales, 107 U. PA. L. REv. 299 (1959); Lagergren, $A$ Uniform Law of International Sales of Goods, 1958 J. Bus. L. 131 ; Piot, Unification of Law of International Sale, 84 J. DU Droit International 949 (1957). (1938).

18 See Rabel, $A$ Draft of an International Law of Sales, 5 U. CHI. L. Rev. 543

19 For a comparison of the approach to the problem of risk under the Uniform Sales Act and the sales article of the Uniform Commercial Code see Honnold, supra note 17, at 316; Latty, Sales and Title and the Proposed Code, 16 LAW \& Contearp. Prob. 3 (1951).

20 However, no direct trace can be found in the materials prepared for the coming Conference of consideration given to Professor Honnold's observations, supra note 17. The principal points discussed in his article are: the scope of the uniform law and the substantive rules as to the quality of goods, risk of loss, maritime shipments and international trade terms, salvage, and the buyer's right to force delivery as well as the legal concept of delizrance (as distinguished from "delivery"). 
the Commissioners. ${ }^{21}$ The same standard appears to be applicable on the international level. The desirability of unification of the law of international sales of goods is not in doubt, but experts may disagree on the question of practicability. The civil-law countries seem to believe in the practicability for the civil-law world at least. Until recently the law of sales was largely uniform in the common-law world. The Uniform Sales Act of 1906, enacted in most of the states of the Union, ${ }^{22}$ has as its basis the British Sale of Goods Act of 1893 which is in force in most of the British Commonwealth. ${ }^{23}$ Today the uniformity is quickly disappearing with adoption by a growing number of the states of the Union of the Uniform Commercial Code. ${ }^{24}$ The split among the common-law jurisdictions will disappear if Great Britain and other members of the British Commonwealth adopt in due course the improvements found in the sales law of the Uniform Commercial Code. The Code's sales article and the draft to be discussed at the coming Diplomatic Conference are not far apart from each other on fundamentals. Consequently, agreement on substantial unification appears possible.

In this country, the practical importance of a uniform law for international sales of goods is unquestioned. Palliatives are used today to limit the dangers coming from lack of uniformity, but they are inadequate substitutes. Recourse is had to form contracts elaborated by trade associations, to uniform definitions of trade terms promoted by national and international organizations, to choice of law and jurisdiction clauses which may, or may not, be valid, and to provision for arbitration, considered by some as a cure-all.

Unfortunately, the time chosen for the coming meeting is not the best to secure active participation of and support from the United States which, until recently, had no link with the Rome Institute or the Hague Conference on Private International Law. Only at the end of December 1963 was the President authorized by Congress to accept for the United States Government membership in the two organizations. ${ }^{25}$

This legislative development was no surprise to persons familiar with unification of law work here and abroad. The United States has

21 See Constitution of the National Conference art. I, $\$ 2$, in Natronal CoNFERENCE OF COMMISSIONERS ON UNIFORM STATE LAWS, 1962 HANDBOOK 298.

22 At one time it was in force in 36 states and the District of Columbia. See 1 UNIFORM LAWS ANNOTATED 1 (1950).

2356 \& 57 Vict., c. 71; see Chalmers, Sale of Goods ACt (12th ed. 1945).

24 See Braucher, The Progress of the Uniform Commercial Code, 11 AM. J. Comp. L. 293 (1962); Malcolm, The Uniform Commercial Code in the United States, 12 INT'L \& CoMP. L.Q. 226 (1963).

25 Pub. L. No. 244, 88th Cong., 1st Sess. (Dec. 30, 1963) ; see S. REP. No. 781, 88th Cong., 1st Sess. (1963); H.R. ReP. No. 873, 88th Cong., 1st Sess. (1963). 
had a long record of nonparticipation in international work on unification of law, but, since 1956, a change in policy has clearly been in the making. Criticism of the Administration in the postwar period for not protecting American interests in unification work on the international level ${ }^{26}$ led to a decision to send an official Observer Delegation to the 1956 session of the Hague Conference on Private International Law; and the same procedure was followed for the 1960 session. The Observers, in their reports, praised the work of the Conference, pointed at the inefficiency of the Observer status, and recommended full membership in the Conference. ${ }^{27}$ The American Bar Association had a Special Committee study the problem ${ }^{28}$ and, in a resolution adopted by the House of Delegates in March 1963, it asked the Government to join the Hague Conference and the Rome Institute. $^{29}$ These developments were not hidden from interested groups abroad. It was hoped that the United States would be represented officially at the next session of the Hague Conference on Private International Law scheduled for October 1964. The expectation was that, as in 1951, the Diplomatic Conference on the revised draft of a Uniform Law on International Sales of Goods would be held immediately following the October 1964 session of the Hague Conference on Private International Law.

Thus the April 1964 date for the Diplomatic Conference came as a surprise to persons in the United States who had followed developments. The surprise was even greater because, since the Fall of 1962, preparations were under way for a conference to be held in New York City in August 1964 under the auspices of the International Association of Legal Science to discuss regional efforts toward unification of the law of sales, particularly the draft of a Uniform

26 See Nadelmann, Ignored State Interests: The Federal Government and International Efforts To Unify Rules of Private Law, 102 U. PA. L. REv. 323, 357-62 (1954).

27 See Amram, The Hague Conference on International Private Law, 1961 A.B.A. Sectron of INT'L \& CoMr. L. Bull. 50; Barrett \& Dezendorf, Report on Ninth Session of the Hague Conference on Private International Laze, in NationaL Conference of Comarissioners oN Uniform State Laws, 1961 Handbook 71-75; Nadelmann, The Hagne Conference on Private International Law-Ninth Session, 9 AMr. J. Coмp. L. 583 (1960) ; Reese, The Ninth Session of the Hague Conference on Private International Law, 55 AM. J. INT'2 L. 447 (1961).

28 See Report of the A.B.A. Special Committee on International Unification of Private Law, 1961 A.B.A. REP. 219.

291963 A.B.A.J. 385, 392. Recommendations to the same effect were made by other leading national organizations, in particular the National Conference of Commissioners on Uniform State Laws, the Association of American Law Schools, the American Association for the Comparative Study of Law, the American Society of International Law, and the American Branch of the International Law Association. See Hearings on H.R.J. Res. 732 Before the Subcommittee on International Organizations and Movements of the House Committee on Foreign Affairs, 88th Cong., 1st Sess. 21, 23, 24, 55, 57 (1963). 
Law on International Sales of Goods and the sales article of the Uniform Commercial Code. ${ }^{30}$ In addition, the April 1964 date was chosen in advance of a conference called by the Rome Institute for September 1963 which planned to discuss the relation between regional and international unification of law. ${ }^{31}$

International work on unification of law still operates under the cloud created by the partial failure to unify internationally the law of negotiable instruments. The uniform laws drafted in Geneva in 1930 and 1931 under the auspices of the League of Nations ${ }^{32}$ have been adopted on the European Continent, but the Anglo-American world has focused its attention on the British Bills of Exchange Act of 1882, of which the Uniform Negotiable Instruments Act of 1898 is a replica. ${ }^{33}$ The sponsors of the project to draft a uniform law for international sales of goods were anxious to avoid a repetition of this experience, as evidenced by the composition of the original Committee. Indeed, the Rome draft coming before the Diplomatic Conference of 1951 had many features of the English sales law. The draft met with no basic opposition from the English side at the Conference. ${ }^{34}$

Thus the comments of the United Kingdom on the revised draft which was sent to the governments in 1956 must have come as a shock to the other sponsors of the venture. These comments ${ }^{35}$ say in essence that, judging from the reactions received from representative British business associations, introduction of the uniform law would, under present conditions, be without interest to the British business world. The comments stressed agreement, however, on the fact that, whatever the ultimate reaction of the United Kingdom, introduction of a uniform law in other countries would have important consequences for the United Kingdom; that, therefore, the United Kingdom should cooperate in the preparation of the final text of the uniform law.

The comments underline four or five basic differences between the English law and the draft of a Uniform Law, to indicate the aspects of

30 See 11 Am. J. Comp. L. 690 (1962). LAW.

31 The proceedings of this conference will be printed in 1963 UNIFICATION of

32 See Hudson \& Feller, The International Unification of Lawes Concerning Bills of Exchange, 44 HARv. L. REv. 333 (1932); Feller, The International Unification of the Lazes Concerning Checks, 45 HARV. L. REv. 668 (1933).

33 See Yntema, Unification of the Laws Respecting Negotiable Instruments, 4 INT'L \& Comp. L.Q. 178 (1951). For the attitude of the United States Government toward the project see Nadelmann, Ignored State Interests: The Federal Government and International Efforts To Unify Rules of Private Law, 102 U. PA. L. Rev. 323, 343 (1954).

34 See Rabel, The Hague Conference on the Unification of Sales Laze, 1 Ax. J. COMP. L. 58,61 (1952).

35 Commission Speciale, Observations des Gouvernemients et de la CCI sur LE PROJET DE LOI UNIFORME SUR LA VENTE INTERNATIONALE DES OBJETS MOBILIERS CORPORELS 44 (1963). 
the draft with which the business world in England is not familiar, since adoption of the law depends on their support. The principal differences listed involve rules of the English Sale of Goods Act (and of the American Uniform Sales Act) which the sales article of the Uniform Commercial Code has deliberately eliminated to improve the law. Others are matters of detail which appear worthy of consideration but on which no comment is found in the Observations of the Special Committee which accompany its revised final draft. The business world in England has, clearly, been unaware of the reform of the sales law in the United States. This is borne out by the status of the English legal literature on the subject. ${ }^{36}$ The comments, indeed, make no reference to the developments in the American law.

Examination of the "parliamentary" situation at the new Conference raises several questions. In the first place, most of the "old guard" with which the project originated have gone: Scialoja, Gutteridge, Capitant and Hamel, Fehr and Ussing, Meijers and Rabel, all internationally famous lawyers, are dead. Some of the drive, and knowledge also, may have been lost. Up to this day, no evaluation is found in any foreign source of the effect on the project of the adoption in the United States of the sales article of the Uniform Commercial Code. However, the emergence of the European Economic Community has produced a strong movement in favor of unification of the law of the Common Market countries. President De Gaulle's view on "Anglo-Saxon" participation in the Common Market is only one sign of growing regional nationalism if not chauvinism. The question is asked by some whether it is worth waiting for United Kingdom and United States participation in endeavors such as the projected unification of the law of international sales of goods, and the intentions of the common-law countries are questioned in some quarters.

The American lawyer knows that unification of law requires selling of the produced project to the legal profession and the public. Little if anything has been done so far to sell the sales project to Englishspeaking nations. The principal materials, including the Proceedings of the 1951 Conference and the materials prepared for the 1964 Conference, are in French. Only the draft of 1956 has been translated, and its evaluation is not possible without full study of both the comments from the governments and the observations of the Special Committee on these comments. Anglo-American participation in unification clearly suggests a different type of preparation.

36 The first comprehensive publication in England seems to have been Malcolm, supra note 24; cf. Wortley, Great Britain and the Movement for Unification of Private Law Since 1948, 32 TuL. L. REv. 541 (1958). 
The language question continues to be a problem. In 1951, the Diplomatic Conference adopted the Rules of the Hague Conference on Private International Law ${ }^{37}$ which provide only for the use of French. When the Hague Conference drafted its permanent Charter at the October 1951 session, a delegate of the United Kingdom suggested the use of English and referred to the possibility of future American participation in the Hague Conference. This possibility was held not imminent, and it was decided to continue with the established customs and leave the matter to the Regulations. ${ }^{38}$ At the 1956 session, when American Observers made their first appearance, the Conference provided them with interpreters. At the 1960 session, simultaneous translation was used, and a number of delegates, especially several from Scandinavia and Japan, used the English language. But the proceedings are still in French, and the only advance made is that, at the end of the 1960 session, the English and American delegates joined with the Conference staff to produce unofficial English versions of the new draft conventions. Obviously, when the United States joins the Hague Conference, the language question will be settled in line with the general practice followed by other international organizations. In fact, the Rome Institute, sponsor of the Uniform Sales Law draft, has published its valuable Yearbook in both French and English since 1948.

American participation in the project also raises the problem of implementation of any agreement on a uniform text which may be obtained. The Diplomatic Conference of 1951 was called to consider a "draft convention relating to a uniform law on international sales of goods," and this formula is also in the opening paragraph of the Final Act of the Conference. ${ }^{39}$ The product of the Special Committee prepared for the coming Conference is a draft of a uniform law without covering convention, and no assignment had gone to the Committee for this purpose. But the Committee's draft, in article 3, suggests the existence of a convention, and the Committee's comments on the first three articles speak of it. Also, the tradition has been on the Continent, though not among the Scandinavian countries, to make uniform legislation the subject of binding international agreements. The question is whether the Diplomatic Conference will proceed along this "traditional" line.

At the 1956 session of the Hague Conference on Private International Law, the United States Observers pointed out the possibility

37 See Actes 84.

38 Conférence de la Haye de Droit International Prive, Actes de la Septième Session 334-38 (1952).

39 See ActEs 3, 269. 
of proceeding without binding conventions through free enactment of agreed-upon uniform legislation, ${ }^{40}$ and there has been heated argument pro and con this possibility. ${ }^{41}$ The method of free, nonbinding, agreement, used successfully in the United States and Canada, by the Scandinavian countries, and also among members of the British Commonwealth, has been anathema to a large group of continental jurists, especially of the older-age group. The opposition came, it is true, primarily from persons unfamiliar with the method, and the "storm" seems to have abated somewhat. Yet the question remains, and, whatever the position of the United Kingdom, in the United States any suggestion of making binding commitments will probably be met with disfavor, even though the subject comes under the commerce clause ${ }^{42}$ and no "constitutional" problem about using the treaty-making power arises.

At the Hague Conference on Private International Law the question of "method" has come to a rest, temporarily at least, by adoption at the 1960 session of a resolution reaffirming the use, "in the first place," of international conventions, but recommending the presentation of the contents of conventions in such a way that they can be introduced easily as a piece of legislation. ${ }^{43}$ For the regulation of some conflicts problems the use of conventions may be unavoidable. On the other hand, no need exists for implementing an agreement on a uniform law for international sales of goods by way of a binding international commitment. Should a group of states wish to commit themselves in such a way, this would be their privilege; but nothing would, or should, prevent other states from freely incorporating the agreed-upon uniform text-or its principles-into their legislation. These states would have the advantage of being able to change the law unilaterally as defects are recognized. Experience with the Uniform Commercial Code has shown that again it is likely that such defects will arise. ${ }^{44}$ Indeed, as in the case of the Code, in order to maintain uniformity, the institution which produced the uniform law would have to be continued to

40 See Nadelmann \& Reese, The American Proposal at the Hagne Conference on Private International Law To Use the Method of Uniform Laws, 7 AM. J. Comp. L. 239 (1958).

41 See Nadelmann, Ways To Unify Conflicts Rules, 9 NederLands TijdschrIft VOOR INTERNATIONAAL RECHT 349 (1962).

42 U.S. Const. art. 1, §8.

43 See Nadelmann, The Hague Conference on Private International LawNinth Session, 9 Arr. J. CoMr. L. 583, 594 (1960).

44 See Malcolm, supra note 24, at 241-44; Permanent Editorial Board for the UNIFORAI CoMmercial CODE, REPoRT No. 1 (1962); cf. Peters, Remedies for Breach of Contracts Relating to the Sale of Goods Under the Uniform Commercial Code: A Roadmap for Article Two, 73 Y ALE L.J. 199, 287 (1963). 
follow the law's operation in practice and make recommendations for uniform amendment if indicated. ${ }^{45}$

The observations of the Special Committee on the comments by various governments on the $1956 \mathrm{draft}$ indicate the existence of a large number of points on which the drafting group and some governments disagree. Within the limited time available, the Diplomatic Conference will, in all likelihood, find it difficult to settle all these issues and others which may arise. Thus the Conference may not reach the "political" question of how to implement any agreement reached; and, for other reasons, the project does not seem to be sufficiently advanced in any event for final action if international unification of the law of international sales of goods is to be attained.

The record up to and including the 1951 Conference clearly indicates an intention on the part of the sponsors to unify the law of international sales internationally, and not merely regionally. "International Sales of Goods," if spoken of by merchants in the Western World, includes trading with all parts of that world. The exporter or importer of goods on the European Continent has in mind trade with North and South America, with the Near and Far East, with Australia, as much as trade relations with neighboring countries. Common sense thus suggests the unification of the law of international sales of goods for the entire Western World if practicable. Regional unification, for Continental Europe, or for the Common Market of the Six, would be the "second choice" if the broader plan fails.

With this as a premise, the preparation of the coming Diplomatic Conference is clearly defective, in part because matters of consequence have happened since the first Conference which could not be anticipated and which have not been taken into account. But even as of 1951, the arrangements then made for production of a new draft were inadequate. Granted that a Rabel and others put by the Conference on the Special Committee had a "universal" knowledge of sales law, the choice of only Europeans for service on the Committee was unwise if production of a universally acceptable draft was hoped for. Even a Rabel, representing the Rome Institute, could not think in terms of the specific problems and interests of the thirty or more governments then members of the Institute.

Many changes in circumstances must be considered in evaluating the situation at the present time. In the United States, adoption of the revised sales law through the Uniform Commercial Code has become a reality. Enactment of the Code in all states of the Union is

45 Cf. Nadelmann, Uniform Interpretation of "Uniform" Laz, 1959 UNIFICATION of LAw 383. A "Postscript" will appear in 1963 UNIFICATron OF LAw. 
expected. And if, in 1951, no signs existed of American interest in international unification of law, matters have changed for the better. The American lawyer has become conscious of his international responsibility. ${ }^{46}$ Regardless of the situation in the British Commonwealth in 1951, direct representation for Canadian, Australian, and Indian interests is now a practical necessity. ${ }^{47}$ The complete omission of representation of Latin America on the Special Committee was shortsighted even for $1951 .{ }^{48}$ The same is true for nonrepresentation of Japan and other important trading nations. Although limitation of representation on the original drafting committee to the principal types of legislation on sales was proper, a different approach is needed for production of a final draft. The difficulty of working with large committees can be overcome through assignment of spade work to subcommittees.

This being said, it should be emphasized that very considerable progress has been made since 1951 with the work on the draft of a uniform law of international sales of goods. Many of the more serious difficulties have apparently been solved to the satisfaction of a large number of European nations. On the basis of this preparation, the second Diplomatic Conference should be able to do useful work during the three-week period at its disposal. The final stage of the work can be planned at the same time. It will be crucial for the success of the whole enterprise.

Conscious of the American interest in the project and of their own involvement, the Commissioners of Uniform State Laws decided at the annual meeting of the Conference in August 1963 to do their own investigation of the situation, as far as the Uniform Commercial Code is concerned. ${ }^{49}$ While the primary focus remains on securing the enactment of the Code in the states of the Union which have not yet enacted it, simultaneous investigation of the possibilities of an international agreement on a uniform law to cover international sales of goods is possible, and such investigation is presently in effect. The existence of the Permanent Editorial Board for the Uniform

46 See Report of the A.B.A. Special Committee on International Unification of Private Laze, 1961 A.B.A. REP. 219, 250.

47 See Harris, Canadian Reaction to the Uniform Commercial Code, 11 Ax. J. Conp. L. 302 (1962); cf. Leach, The Uniform Law Movement in Australia, 12 As. J. CoMrp. L. 206 (1963).

48 The Inter-American Juridical Committee has had unification of the law of international sales of goods on its agenda. See Inter-American Juridical Committee, Report on Work Accomplished During Its 1961 Meeting 5 (mimeo ed. 1962).

49 See National Conference of Commissioners on Uniform State Laws, 1963 HANDBOOK. 
Commercial Code facilitates the investigation. Implementation of an international agreement could be by amendment or addition to the Uniform Commercial Code, if not through federal legislation.

In England, second thoughts seem to have been given to the situation, especially in the light of the revision of the sales law accomplished in the United States. The British Institute of International and Comparative Law has called a one-day meeting for the end of January 1964 inviting guests from the Continent to acquaint its members with the draft of a uniform law on international sales of goods and the problems of the coming Diplomatic Conference.

Dr. Rabel and others have drawn attention to the fact that many failures in unification work have been due to inadequate planning. Unification depends as much on statesmanship as on expertise in the law. In the instant case, efforts have been almost exclusively on the technical side of the problem. While a Special Committee was chosen to produce a revised draft, no provision was made for the active consideration by the leading commercial nations of the world of the "political" question of securing adoption of an agreed-upon law, or of the basic principles of such law. Yet the two matters must be considered simultaneously, and the technical experts are not necessarily the best to handle the "political" aspects. The history of unification work shows the impossibility of "selling" a draft produced without due consideration of the "climate."

In 1951, no provision was made for a steering committee, and establishing an efficient one might have been difficult. Suffice it to recall the passive if not negative attitude of the principal trading nation, the United States, at that time. Today, with an advanced draft available, the attention of governments, business circles, and international lawyers is easy to obtain. Thus the delay in acting on the "political" side may have helped save the project.

Considerable experience in unification work has accumulated. The Maritime Law Conferences could not have been successful without the preparatory work of the International Maritime Committee which is as politically minded as it is expert in maritime law. The same can be said of machinery used for work in other special areas of the law. For international sales, now handled on an ad hoc basis, a similarly efficient body to cover the "political" side of the project is needed. The machinery of the Rome Institute, promoter of the original project, could perhaps be used for steering committee functions, or the Diplomatic Conference might set up a steering committee which would have the assistance of the Institute. Obviously the principal trading nations must be represented on such a steering committee. 
The task that lies ahead is easy to discern if the complete lack of publicity given to the project outside Europe is considered. This is no way of achieving unification of the law of international sales in the Western World. The argument seems to be made today in some quarters of Continental Europe that excessive time has been spent on the project and that the moment for action has come. Unfortunately, the time has been used poorly for promotion of the project. Rightly or wrongly, Americans are criticized for putting too much efforts on "promotion" of projects. Yet worldwide projects cannot be brought to success when they remain the guarded secret of a few. If ours is the "period of comparative' law," transformation of the results of comparative law research into action on the international level is still in its infancy.

Unification of the law of international sales of goods is of paramount importance to international trade. Thus the project must be treated accordingly and its failure prevented. The forthcoming Diplomatic Conference furnishes an occasion, possibly the last, to lay the ground for the successful outcome of the well-conceived plans of the originators of the idea. Statesmanship is-and remains-needed. The worldwide aspects of the project must be duly considered. If the world has become even more complicated than it was in the 1930's or in 1951, unification of the law of international sales, or its harmonization, for the needs of the business community of the world is not beyond human possibilities. 